\title{
System-L amino acid transporters play a key role in pancreatic $\beta$-cell signalling and function
}

\author{
Qi Cheng1,*, Violeta D Beltran², , Stanley M H Chan³, Jeremy R Brown², \\ Alan Bevington ${ }^{2}$ and Terence $\mathbf{P}$ Herbert ${ }^{3, *}$
}

${ }^{1}$ Research School of Biology, Australian National University, Acton, Australia ${ }^{2}$ Department of Infection, Immunity and Inflammation, University of Leicester, UK ${ }^{3}$ Health Innovations Research Institute (HIRI), School of Medical Sciences, RMIT University, Bundoora, Australia ( ${ }^{*}$ Q Cheng, V D Beltran and T P Herbert were previously at the Department of Cell Physiology and Pharmacology, University of Leicester, UK)

Correspondence should be addressed to T P Herbert

Email

terence.herbert@rmit.edu.au

\begin{abstract}
The branched-chain amino acids (BCAA) leucine, isoleucine and valine, are essential amino acids that play a critical role in cellular signalling and metabolism. They acutely stimulate insulin secretion and activate the regulatory serine/threonine kinase mammalian target of rapamycin complex 1 (mTORC1), a kinase that promotes increased $\beta$-cell mass and function. The effects of BCAA on cellular function are dependent on their active transport into the mammalian cells via amino acid transporters and thus the expression and activity of these transporters likely influence $\beta$-cell signalling and function. In this report, we show that the System- $L$ transporters are required for BCAA uptake into clonal $\beta$-cell lines and pancreatic islets, and that these are essential for signalling to $\mathrm{mTORC1}$. Further investigation revealed that the System-L amino acid transporter 1 (LAT1) is abundantly expressed in the islets, and that knockdown of LAT1 using siRNA inhibits mTORC1 signalling, leucine-stimulated insulin secretion and islet cell proliferation. In summary, we show that the LAT1 is required for regulating $\beta$-cell signalling and function in islets and thus may be a novel pharmacological/nutritional target for the treatment and prevention of type 2 diabetes.
\end{abstract}

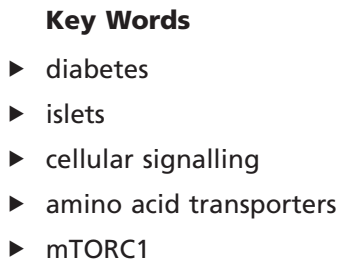

Journal of Molecular Endocrinology (2016) 56, 175-187

\section{Introduction}

The branched-chain amino acids (BCAA), leucine, isoleucine and valine, are essential amino acids that play an important role in glucose homeostasis. In vitro, leucine stimulates insulin secretion (Newsholme et al. 2007) and improves insulin secretory function of human islets (Yang et al. 2006). Studies on the effect of diets containing increased BCAA or leucine on glucose homeostasis in vivo have been contradictory, likely due to differences in diet regimens and models. However, there is evidence that high protein diets, a source of BCAA, or leucine supplementation enhances insulin secretion and glucose clearance in healthy adults and type 2 diabetics (Linn et al. 1996, van Loon et al. 2003, Kalogeropoulou et al. 2008, Leenders \& van Loon 2011). Moreover, human neonates fed high protein formula milk have significantly raised serum leucine which parallels increased C-peptide (Socha et al. 2011).

Branched-chain amino acids, and particularly leucine, are also critical for the activation of mammalian target of rapamycin complex 1 (mTORC1), as they 
promote the translocation of mTORC1 to GTP-loaded Rheb, its upstream activator located at the lysosome (for review see Bar-Peled \& Sabatini 2014). This process is dependent on a complex of proteins including RAGS (RAS-related GTPases), the Ragulator, v-ATPase, GATOR (GAP activity towards RAGS) and folliculin. Yet how changes in the amino acid concentration are sensed is still unclear. Although there is growing evidence to suggest that changes in the intra-lysosomal concentration play a significant role. Importantly, mTORC1 is a kinase whose hyperactivation in mice has been shown to stimulate both pancreatic $\beta$-cell function and mass (for reviews see Blandino-Rosano et al. 2012, Xie \& Herbert 2012). For example, $\beta$-cell-specific deletion of tuberous sclerosis complex-2 (Tsc2), a negative regulator of mTORC1, or $\beta$-cell-specific expression of constitutively active Rheb, a small $\mathrm{G}$ protein which binds to and activates mTORC1, results in increased $\beta$-cell mass due to increased proliferation and cell size (Rachdi et al. 2008, Balcazar et al. 2009). Mice expressing constitutively active protein kinase $\mathrm{B}(\mathrm{PKB})$ in $\beta$-cells also have increased $\beta$-cell mass due to increased mTORC1 activity (Elghazi et al. 2007). Therefore, BCAA-dependent activation of mTORC1 may be important in $\beta$-cell compensation and hence in protecting against the development of type 2 diabetes.

The effects of amino acids on $\beta$-cell signalling, function and mass are likely mediated through changes in their intracellular concentration. Importantly, amino acid transporters play an important part in determining the size and composition of the intracellular amino acids pool. There are several amino acid transporter Systems facilitating the transport of BCAAs, including System $\mathrm{B}^{0,+}$, System $\mathrm{y}+\mathrm{L}$, and System $\mathrm{b}^{0,+^{* *}}$ and System-L (Hyde et al. 2003). The System-L amino acid transporters (LATs) are high-affinity transporters of large neutral amino acids (i.e., the BCAA and aromatic amino acids) that are competitively inhibited by 2-aminobicyclo-(2,2,1)-heptane-2-carboxylic acid (BCH), a non-metabolisable analogue of L-leucine. There are four members of this group called large neutral amino acid transporters or LATs. LAT1 and LAT2 are heterodimeric and are composed of a 'light subunit' that serves as an amino acid permease and a 'heavy subunit': glycoprotein CD98 (cluster of differentiation 98) protein (encoded by SLC3A2) aka 4F2HC (4F2 cell-surface antigen heavy chain), that facilitates translocation of LAT to the plasma membrane (Verrey 2003). In contrast LAT3 and LAT4 are made up of a single subunit and does not require CD98 for transport activity (Bodoy et al. 2005). Surprisingly, the amino acid transporter/s responsible for the uptake of BCAA into $\beta$-cells has remained largely unexplored. Moreover, their potential role in regulating mTORC1 activity and $\beta$-cell function is essentially unknown. In this report, we demonstrate that System-L transporters are required for signalling to mTORC1 in $\beta$-cells. We also show that LAT1 is the most predominately expressed transporter in islets and that this transporter plays an important role in regulating both $\beta$-cell signalling and function.

\section{Materials and methods}

\section{Chemicals and media}

All chemicals and media were purchased from Sigma-Aldrich unless otherwise stated. EBSS (Earle's Balanced Salt Solution) contained $20 \mathrm{mM}$ glucose, $2 \mathrm{mM}$ L-glutamine and $\mathrm{P} / \mathrm{S} / \mathrm{N}(50 \mu \mathrm{g} / \mathrm{mL}$ streptomycin, 50 units/mL penicillin sulphate and $0.1 \mathrm{mg} / \mathrm{mL}$ Neomycin) and the $\mathrm{pH}$ was adjusted to 7.4 using $\mathrm{NaHCO}_{3}$. MEM essential amino acids solution $(1 \times)$ was made from a $50 \times$ MEM stock (Sigma M5550) and contained 0.1264g/L L-Arg. $\mathrm{HCl}, \quad 0.03128 \mathrm{~g} / \mathrm{L} \quad$ L-Cys. $2 \mathrm{HCl}, \quad 0.042 \mathrm{~g} / \mathrm{L} \quad$ L-His $\mathrm{HCl} \cdot \mathrm{H}_{2} \mathrm{O}, 0.0525 \mathrm{~g} / \mathrm{L}$ L-Ile, $0.0524 \mathrm{~g} / \mathrm{L}$ L-Leu, $0.0725 \mathrm{~g} / \mathrm{L}$ L-Lys.HCl, $0.0151 \mathrm{~g} / \mathrm{L}$ L-Met, $0.033 \mathrm{~g} / \mathrm{L}$ L-Phe, $0.0476 \mathrm{~g} / \mathrm{L}$ L-Thr, $0.0102 \mathrm{~g} / \mathrm{L} \mathrm{L-Typ,} 0.036 \mathrm{~g} / \mathrm{L} \mathrm{L-Tyr}$, and $0.0468 \mathrm{~g} / \mathrm{L}$ L-Val. MEM essential amino acid mixture $(1 \times)$ without System-L amino acids was made using individual amino acids purchased from Sigma and contained 0.1264 g/L L-Arg. $\mathrm{HCl}, \quad 0.03128 \mathrm{~g} / \mathrm{L} \quad$ L-Cys. $2 \mathrm{HCl}, \quad 0.042 \mathrm{~g} / \mathrm{L} \quad$ L-His $\mathrm{HCl} \cdot \mathrm{H}_{2} \mathrm{O}, \quad 0.0725 \mathrm{~g} / \mathrm{L}$ L-Lys.HCl, $0.0151 \mathrm{~g} / \mathrm{L}$ L-Met, and $0.0476 \mathrm{~g} / \mathrm{L}$ L-Thr. DMEM minus leucine media was made in-house from its constituent components.

\section{Cell culture and treatment}

Rat insulinoma 1E (INS1E) cells (Merglen et al. 2004) were maintained in a humidified incubator (95\% air, 5\% $\left.\mathrm{CO}_{2}\right)$ at $37^{\circ} \mathrm{C}$ in RPMI-1640 medium containing $11.1 \mathrm{mM}$ glucose, supplemented with $5 \%(\mathrm{v} / \mathrm{v})$ heat inactivated fetal bovine serum (FBS) (Invitrogen, Thermo Scientific Inc, Waltham, MA, USA), $1 \mathrm{mM}$ sodium pyruvate, $10 \mathrm{mM}$ HEPES, $55 \mu \mathrm{M} \beta$-mercaptoethanol and $\mathrm{P} / \mathrm{S} / \mathrm{N}(50 \mu \mathrm{g} / \mathrm{mL}$ streptomycin, 50 units $/ \mathrm{mL}$ penicillin sulphate and $0.1 \mathrm{mg} / \mathrm{mL}$ Neomycin). Before treatments, INS1E cells were serum starved overnight (16h) in CMRL-1066 medium containing $0.5 \mathrm{mM}$ L-glutamine and $\mathrm{P} / \mathrm{S} / \mathrm{N}$. The cells were treated as described in the figure legends.

Pancreatic islets were isolated from Male Wistar Albino rats weighing 200-250g and dissociated as described previously (Moore et al. 2011). The dispersed cells were plated on a poly- D-lysine coated plates and incubated in

Published by Bioscientifica Ltd. 
RPMI-1640 media containing 10\% FBS and P/S/N. The cells were treated as described in the figure legends.

\section{SDS-polyacrylamide gel electrophoresis and Western blot analysis}

SDS-Page and Western blotting were performed as described previously (Moore et al. 2009) using anti-phospho Akt/PKB (Ser473), anti-Akt/PKB, anti-phospho S6K1(Thr389), antiphospho ribosomal protein S6 (Ser240/244) and anti-LC3 A/B from Cell signalling Technologies, Beverly, MA, USA, and anti-ribosomal protein S6 obtained from Santa Cruz Biotechnology Inc, Santa Cruz, CA, USA.

\section{Amino acid analysis}

Amino acid analysis was performed essentially as described previously (Evans et al. 2007). After treatments, INS1E or islets of Langerhans were rapidly chilled on ice, rinsed three times with ice-cold $1 \times$ PBS to remove extracellular amino acids and deproteinised by scraping with $150 \mu$ of $0.3 \mathrm{M}$ perchloric acid. The resulting lysate was transferred to microcentrifuge tubes on ice, followed by incubation for at least $30 \mathrm{~min}$. Precipitated protein was sedimented by centrifugation $\left(10 \mathrm{~min}, 4^{\circ} \mathrm{C}, 14,000 \mathrm{~g}\right.$ ) and retained for total protein assay. The supernatant was filtered through a $0.45 \mu \mathrm{m}$ microfilter and was immediately used for determination of amino acids on an Agilent 1100 high-performance liquid chromatograph (Agilent Technologies, Santa Clara, CA, USA) with Zorbax Eclipse AAA column $(4.6 \times 75 \mathrm{~mm}, 3.5 \mu \mathrm{m})$ at $40^{\circ} \mathrm{C}$ with $o$-phthalaldehyde/3-mercaptopropionate/ 9-fluorenylmethylchloroformate precolumn derivatisation and ultraviolet and fluorimetric postcolumn detection.

\section{RNA isolation for qRT-PCR}

peqGOLD Total RNA Kit (VWR international, Germany) was used in RNA extraction for qRT-PCR according to manufacturer's protocol. Islets of Langerhans were cultured for 2 days before RNA extraction. $2 \mu \mathrm{g}$ of total RNA from each extraction were used as a template for reverse-transcription using the SuperScript VILO cDNA Synthesis Kit (Invitrogen). qRT-PCR was then performed on cDNA from 1 ng RNA using gene-specific primers from PrimerDesign (Southampton, UK): Rat LAT1 forward 5'-TTGTTCGTTCAGTAGCACATTG-3' and reverse 5'-ATTCATCGTCCGTTTGTCAGT-3'; Rat LAT2 forward 5'-CCAGTTCCTCTCCCCTCCT-3' and reverse 5'-CAAAGTGAGTGCCATCCTGTC-3'; Rat LAT3 forward 5'-ACACTGAAGTTTTGTCTCCGTTG-3' and reverse 5'-TTGGGCAGAGTAAGTGAGGTAAA-3'; Rat LAT4 forward 5'-CAGAAGCGAGACAGGCAGAT-3' and reverse 5'-TGTAGAGGCAGATTAGGAATGAGG-3'; and 18s RNA primers forward 5'-GTTGGTTTTCGGAACTGAGG-3' and reverse 5'-GCATCGTTTATGGTCGGAAC-3'.

\section{Transfection of siRNAs}

Rat islets of Langerhans were dispersed in a 24-well plate and cultured overnight in rat islet growing medium before transfection with Lipofectamine RNAiMAX (Invitrogen) in Opti-MEM medium (Invitrogen) according to the manufacturer's instructions. For LAT1 knockdown, the cells were transfected for $72 \mathrm{~h}$ with $100 \mathrm{nM}$ on-target plus siRNA (Dharmacon) against Slc7a5 (L-092749-01-0005) or $100 \mathrm{nM}$ Silencer Select Pre-Designed siRNA (Invitrogen) against Slc7a5 (s132356).

\section{Proliferation assay}

Rat islet cell proliferation assays were performed essentially as described previously (Kwon et al. 2006, Xie et al. 2014). A total of 150 rat islets of Langerhans per treatment were used for proliferation assay. Islet cells were starved in RPMI media supplemented with $0.2 \%$ FBS and treated with DMEM $+16.7 \mathrm{mM}$ glucose in the absence or presence of $0.8 \mathrm{mM}$ L-leucine or $2.5 \mathrm{mM} \mathrm{BCH}$ for $48 \mathrm{~h} ; 2 \mu \mathrm{Ci} / \mathrm{mL}$ $\left[{ }^{3} \mathrm{H}\right]$ thymidine was added during the last $24 \mathrm{~h}$. The cells were then collected and washed twice with $1 \times$ phosphate buffered saline (PBS). DNA was precipitated on ice upon the addition of $5 \%$ trichloroacetic acid for $30 \mathrm{~min}$. The samples were centrifuged at $16000 \times \mathbf{g}, 4^{\circ} \mathrm{C}$ for $10 \mathrm{~min}$ and the DNA pellets were then solubilised by adding $0.1 \mathrm{~N} \mathrm{NaOH}$ and incubated for $30 \mathrm{~min}$ at RT. $\left[{ }^{3} \mathrm{H}\right]$ thymidine incorporation was determined by quench-corrected scintillation counting using the LS6500 multi-purpose scintillation counter to detect DPM (disintegrations per minute) in each sample.

\section{Leucine transport assays}

The cells were preincubated for $10 \mathrm{~min}$ in the culture incubator in Leucine-free Krebs Ringer Buffer (KRB). L- $\left[4,5-{ }^{3} \mathrm{H}\right]$ leucine (Perkin Elmer) plus unlabelled L-leucine were then added to the KRB to give a final radioisotope concentration of $5 \mu \mathrm{Ci} / \mathrm{mL}$ and a final total L-leucine concentration of $0.8 \mathrm{mM}$. BCH was also added to some cultures to give a final concentration of $2.5 \mathrm{mM}$. The cultures with ${ }^{3} \mathrm{H}$ were then incubated in the culture incubator for exactly $5 \mathrm{~min}$. The cells were then immediately placed on ice, the medium was aspirated off and the cells were rapidly washed $3 \times$ in ice-cold KRB.

Published by Bioscientifica Ltd. 
0.05 $\mathrm{M} \mathrm{NaOH}$ was then added to the cells and the lysates transferred to microcentrifuge tubes. The lysates were then incubated at $70^{\circ} \mathrm{C}$ for $30 \mathrm{~min}$. A fraction of the lysate was then transferred to a scintillation vial containing Ecoscint A scintillant and allowed to stand for at least an hour to allow chemiluminescence to decay before quenchcorrected scintillation counting using the LS6500 multipurpose scintillation counter. L- $\left[4,5-{ }^{3} \mathrm{H}\right]$ leucine transport rate is expressed as DPM/mg protein/5 min.

\section{Insulin secretion assay}

Following treatments, the test media were collected and centrifuged at $2000 \mathrm{~g}$ for $3 \mathrm{~min}$ to pellet any detached cells. The supernatants were collected and the insulin concentrations measured using a Rat Insulin Enzyme Immunoassay Kit (Bertin Pharma, A05105-96 wells) with rat insulin as a standard in accordance with manufacturer's instructions. The absorbance was read at $414 \mathrm{~nm}$ on the NOVOstar microplate reader.

\section{Statistical analysis}

The results are expressed as means \pm sem. Data were analysed by ANOVA, followed by Bonferroni correction for all pair-wise comparisons or two-tailed paired T-test using GraphPad Prism 6.0. Significance was assigned at $P<0.05$.

\section{Results and discussion}

\section{System-L transporters are critical for $\mathrm{MTORC} 1$ activation in the rodent clonal pancreatic $\beta$-cell line INS1E}

The System-L amino acid transporters are widely expressed, and members of its family are capable of transporting large neutral amino acids including the BCAA. Therefore, we initially investigated the role of the System-L family of amino acid transporters in signalling to mTORC1 in $\beta$-cells.

Clonal rat pancreatic $\beta$-cells (INS1E cells) were treated with insulin to activate mTORC1, in the presence or absence of BCH (2-aminobicyclo- $(2,2,1)$ heptanecarboxylic acid), a competitive inhibitor of System-L, or in the presence or absence of the System-L amino acids substrates: L-Leu, L-Ile, L-Val, L-Phe, L-Tyr and L-Trp (Fig. 1A). As anticipated, the addition of insulin led to a robust increase in mTORC1 activity as determined by the phosphorylation of its downstream target S6 kinase 1 (S6K1) on Thr389 and a substrate of S6K1, ribosomal protein S6 (rpS6), on
Ser240/244. Insulin also stimulated the activation of PKB, as assessed by its phosphorylation on Ser473 (Fig. 1A). The addition of $\mathrm{BCH}$ or the withdrawal of System-L substrates (i.e., L-Leu, L-Ile, L-Val, L-Phe, L-Tyr and L-Trp) significantly inhibited insulin-stimulated mTORC1 activation. In addition, $\mathrm{BCH}$ induced the conversion of cytosolic LC3-I to the lipid-bound LC3-II, which is widely used as the measurement of autophagic flux (Klionsky et al. 2008), indicating that $\mathrm{BCH}$ promotes autophagy, possibly through its inhibition of mTORC1 (Jewell et al. 2013). Interestingly, $\mathrm{BCH}$ also inhibited insulin-stimulated phosphorylation of PKB. In contrast, the withdrawal of System-L amino acids had no significant effect on the conversion of LC3 or on the phosphorylation of PKB. In summary, these results provide good evidence that the System-L transporters play a critical role in signalling to mTORC1 and may also influence autophagy and PKB activity.

The effects of $\mathrm{BCH}$ and the removal of System-L substrates on cellular signalling are possibly mediated by a decrease in the intracellular concentration of BCAA. To investigate this, the effect of BCH or System-L AA withdrawal on the intracellular amino acids pool was determined by HPLC analysis (Fig. 1B). System-L AA withdrawal led to a dramatic decrease in the intracellular concentration of the BCAA, but had no significant effect on the intracellular concentration of the aromatic amino acids, likely reflecting their low rate of catabolism. The addition of $\mathrm{BCH}$ caused a significant decrease in the intracellular concentration of leucine and a trend towards a decrease in the other BCAA, indicating the importance of System-L transporters in the uptake of BCAA in $\beta$-cells. To directly investigate the role of System-L transporters on BCAA transport into INS1E cells, the effect of $\mathrm{BCH}$ on $\left[{ }^{3} \mathrm{H}\right]$ leucine uptake into INS1E cells was also determined (Fig. 1C and E). BCH caused a significant decrease in the uptake of $\left[{ }^{3} \mathrm{H}\right]$ leucine, demonstrating that System-L transporters play an important role in BCAA uptake into INS1E cells.

\section{The uptake of L-leucine through System-L amino transporters is required for MTORC1 activation}

To determine which System-L amino acids are required for signalling to mTORC1, INS1E cells were depleted of System-L amino acids and the effect of the re-addition of each System-L amino acid in turn on the restoration of insulin signalling to mTORC1 was assessed (Fig. 2A). The re-addition of L-Leucine significantly restored insulin signalling to mTORC1, whereas the re-addition of L-Isoleucine, L-Valine, L-Phenylalanine, L-Tyrosine and L-Tryptophan had little-to-no effect on mTORC1. Thus, of

Published by Bioscientifica Ltd. 
A

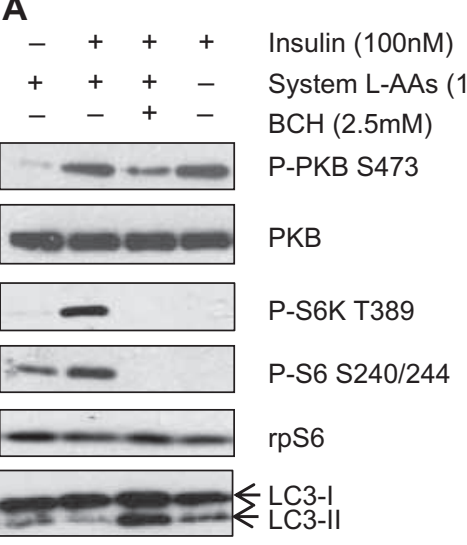

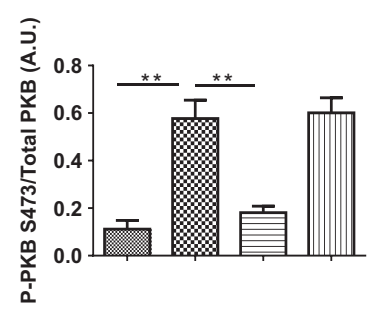
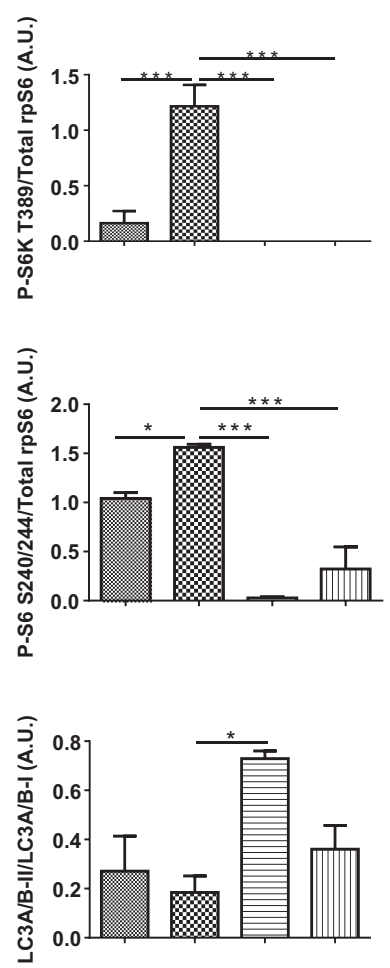
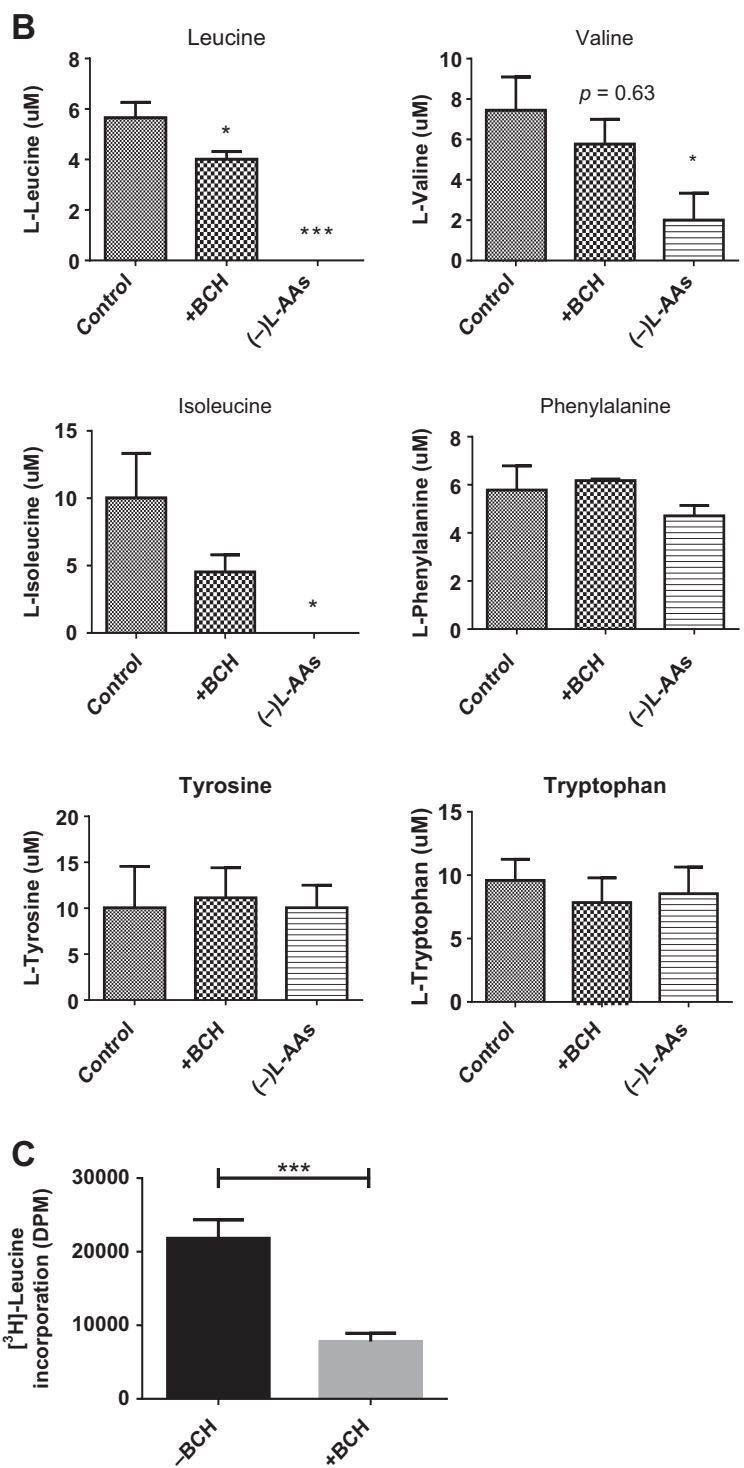

Figure 1

System-L amino acid transporters are required for signalling to mTORC1 in INS1E cells. (A) Serum starved INS1E cells were incubated for 30 min in EBSS (20 mM glucose, 2 mM L-glutamine) supplemented with either 1× MEM essential amino acids (EAA) (+ System-L AAs) or 1× MEM EAA minus the System-L amino acid substrates (- System-L AAs) in the presence or absence of $100 \mathrm{nM}$ insulin $\pm 2.5 \mathrm{mM} \mathrm{BCH}$ as indicated. Proteins were resolved by SDS-PAGE, and Western blotted using antisera against the proteins indicated. The results are graphically represented below showing the mean \pm S.E.M for three independent experiments. ${ }^{* *} P<0.001,{ }^{*} P<0.01$ and $* P<0.05$ compared with insulin plus System-L amino acids. (A.U. $=$ arbitrary unit). (B) Serum starved INS1E cells were incubated for $30 \mathrm{~min}$ in EBSS ( $20 \mathrm{mM}$ glucose, $2 \mathrm{mM}$ L-glutamine) supplemented with either 1× MEM essential amino acids (EAA) and $100 \mathrm{nM}$. insulin. The effect of the addition of BCH $(+B C H)$ or the withdrawal of System-L amino acids ((-)L-AAs) on intracellular amino acid concentration was determined by HPLC analysis. The results are mean \pm S.E.M for five independent experiments. ${ }^{*} P<0.05$ and $* * * P<0.001$ compared with control. (C) L-[ $\left.{ }^{[} H\right]$ Leucine uptake (in the presence of $0.8 \mathrm{mM}$ leucine) in the absence $(-\mathrm{BCH})$ or presence $(+\mathrm{BCH})$ of $2.5 \mathrm{mM} \mathrm{BCH}$. The results presented are the mean \pm s.E.M of 3 independent experiments. ${ }^{* *} P<0.001$ compared with control.

the System-L substrates, only L-Leucine is able to restore insulin signalling to mTORC1. These results confirm and extend previous findings in the rat insulinoma cell line RINm5F and isolated rat islets (Xu et al. 1998).

To investigate whether L-leucine-stimulated mTORC1 activation was indeed dependent upon System-L transporters, INS1E cells depleted of leucine were incubated with $0.8 \mathrm{mM}$ or $0.4 \mathrm{mM} \mathrm{L}$-leucine in the presence or absence of $10 \mathrm{mM} \mathrm{BCH}$ (Fig. 2B). As anticipated, the re-addition of leucine stimulated mTORC1 activation as determined by the phosphorylation of S6K1 and rpS6. Surprisingly, leucine re-addition also inhibited the phosphorylation of PKB on S473 (Fig. 2B). This is possibly mediated by a well characterised mTORC1-dependent feedback mechanism 
A

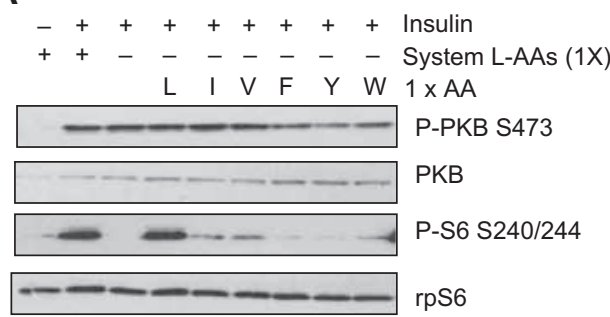

B

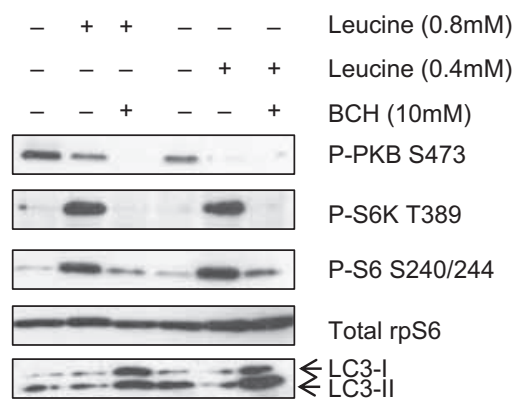

C

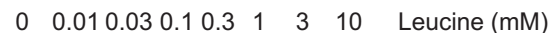
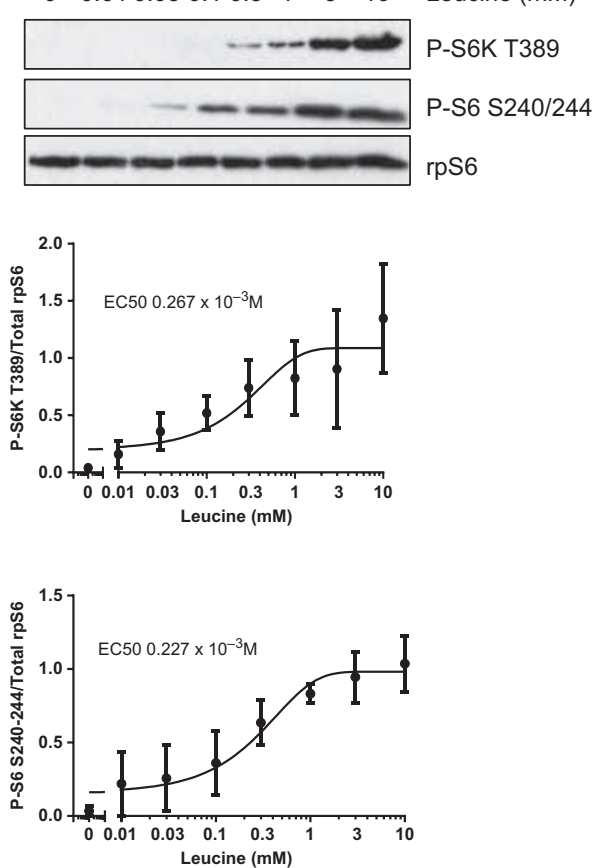

Figure 2

The system-L amino acid substrate leucine is required for signalling to mTORC1 in INS1E cells. (A) Serum starved INS1E cells were incubated for 30 min in EBSS containing $20 \mathrm{mM}$ glucose, $2 \mathrm{mM}$ L-glutamine supplemented with either 1 MEM EAA (+ System-L AAs) or 1× MEM EAA minus System-L amino acids (- System-L AAs) in the presence or absence of each individual System-L amino acid substrate (single letter amino acid code) as specified. Where indicated, $100 \mathrm{nM}$ Insulin (insulin) was also included. (B) BCH inhibits leucine-stimulated mTORC1 activation in INS1E cells. INS1E cells were preincubated in DMEM minus L-leucine for $1 \mathrm{~h}$. The cells were then incubated for a further $30 \mathrm{~min}$ in DMEM minus leucine supplemented with either $0.8 \mathrm{mM}$ or $0.4 \mathrm{mM}$ leucine in the presence or absence of $2.5 \mathrm{mM} \mathrm{BCH}$. (C) Leucine stimulates mTORC1 in a dose-dependent manner. INS1E cells were pre-incubated in DMEM minus L-leucine for $1 \mathrm{~h}$, followed by $30 \mathrm{~min}$ treatment in DMEM minus leucine supplemented with increasing concentration of L-leucine as indicated. Leucine concentration response curves and corresponding EC50 are shown below. The results presented are the mean ( \pm S.E.M) of at least three independent experiments. (D) INS1E cells were pre-incubated in DMEM minus L-leucine for $1 \mathrm{~h}$. The cells were then incubated for a further $30 \mathrm{~min}$ in DMEM minus leucine supplemented with either $0.8 \mathrm{mM}$ leucine in the presence or absence of $10 \mu \mathrm{M}$ Nifedipine. In all cases, proteins were resolved by SDS-PAGE, and Western-blotted using antisera against the proteins indicated. All results are representative of at least three independent experiments.

in which S6K phosphorylates insulin receptor substrate and inhibits insulin signalling (Harrington et al. 2004, Tremblay et al. 2007). Importantly, in the presence of BCH, leucine-stimulated mTORC1 activation was inhibited. Moreover, BCH inhibited PKB and induced autophagy as assessed by the conversion of cytosolic LC3-I to the lipidbound LC3-II (Fig. 2B).

In order to define the EC50 of L-leucine to activate mTORC1, INS1E cells preincubated in leucine-free media were treated for $30 \mathrm{~min}$ with increasing concentrations of L-leucine (Fig. 2C). L-Leucine activated mTORC1 in a dosedependent manner with EC50s of $267 \mu \mathrm{M}$ and $227 \mu \mathrm{M}$ for S6K1 and rpS6 phosphorylation, respectively, with a maximum response at approximately $2 \mathrm{mM}$ (Fig. 2C). Nifedipine, an L-type VGCC inhibitor, is unable to block leucine-stimulated activation of mTORC1 (Fig. 2D) and thus the effects of leucine on mTORC1 are not due to leucine-stimulated insulin secretion.

To investigate the temporal regulation of mTORC1 activation upon leucine re-addition or withdrawal, INS1E cells were either depleted of leucine (Fig. 3A) or leucine added to leucine-starved cells (Fig. 3B) for up to $30 \mathrm{~min}$, and changes in PKB and mTORC1 activity were determined (Fig. 3). The phosphorylation of S6K1 at Thr389 and rpS6 rapidly decreased within $10 \mathrm{~min}$ of L-leucine withdrawal, and further decreased to an undetectable level by $15 \mathrm{~min}$ (Fig. 3A). The phosphorylation of PKB at Ser473 was also significantly decreased by $5 \mathrm{~min}$ of L-leucine withdrawal; however, PKB phosphorylation started to recover by $15 \mathrm{~min}$ and returned to basal levels by $30 \mathrm{~min}$ (Fig. 3A). In addition, the conversion of LC3-I to LC3-II increased within $5 \mathrm{~min}$ of L-leucine withdrawal, indicating the induction of

Published by Bioscientifica Ltd. 
autophagy (Fig. 3A). The re-addition of leucine to leucinestarved cells caused a rapid (within 5-10 min) increase in mTORC1 activation as determined by the phosphorylation of S6K1 and rpS6 (Fig. 3B). The phosphorylation of PKB at Ser473 also rapidly decreased but returned to basal levels by $30 \mathrm{~min}$ (Fig. 3B). In addition, the abundance of LC3-II rapidly decreased, indicating an inhibition of autophagy (Fig. 3B). Given the rapidity of these events, we investigated whether these changes in mTORC1 activity correlated with changes in the intracellular leucine concentration (Fig. 3C). The withdrawal of extracellular leucine for 10 min resulted in the depletion of intracellular leucine whereas within $10 \mathrm{~min}$ of its re-addition the intracellular concentration of leucine returned to basal levels (Fig. 3C). Thus under these conditions, changes in the extracellular concentration of leucine are rapidly mirrored by changes in their intracellular concentration, which reflect the activation state of mTORC1.

\section{System-L transporters are required for islet cell function and signalling to $\mathrm{mTORC1}$}

Having established the importance of System-L transporters in clonal pancreatic $\beta$-cells, we wished to investigate their potential role in primary $\beta$-cells (Fig. 4). Therefore, islets of Langerhans were isolated from rats and deprived of leucine before re-addition of the System-L substrate L-leucine in the presence or absence of $\mathrm{BCH}$ (Fig. 4A). The re-addition of L-leucine significantly stimulated mTORC1, as determined by the phosphorylation state of S6K1 at Thr389 and rpS6 on S240/244, and reduced the phosphorylation of PKB at Ser473. The co-addition of BCH significantly inhibited leucine-stimulated mTORC1 activation and also induced autophagy as measured by the conversion of LC3-I to LC3-II (Fig. 4A). These results are similar to that observed in INS1E cells (Fig. 2).
A
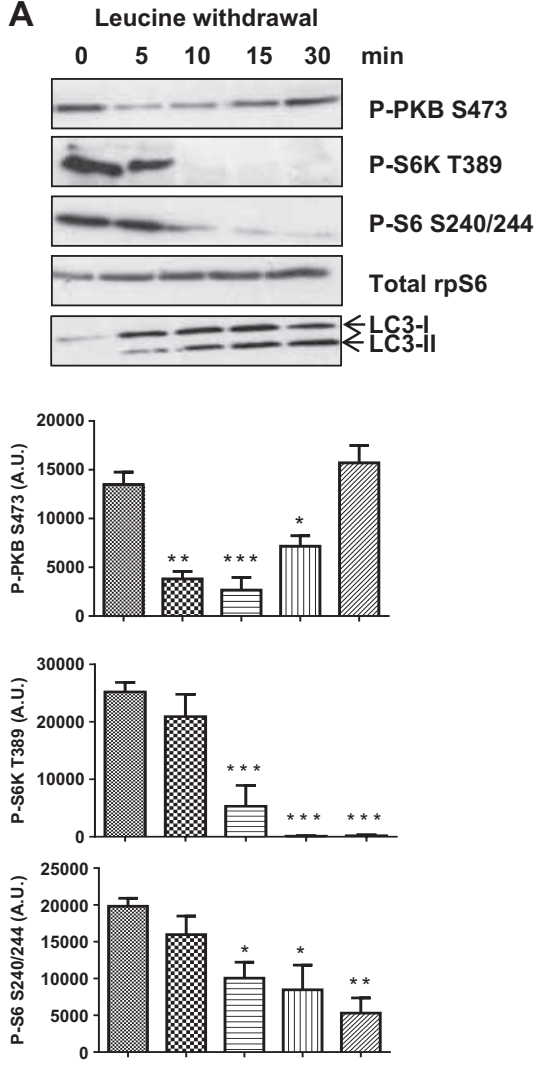

B
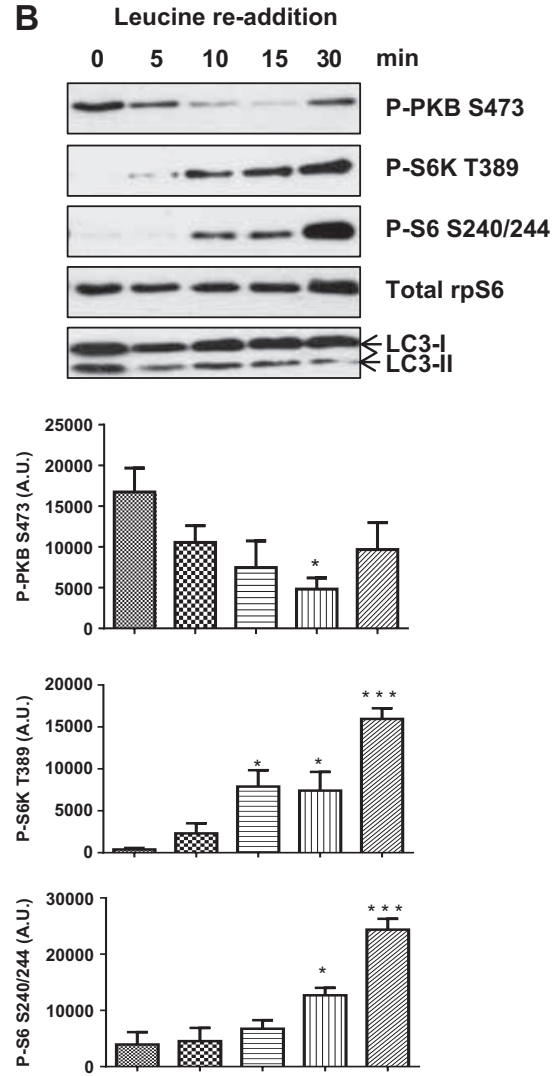

Figure 3

The temporal kinetics of leucine-dependent mTORC1 activation. INS1E cells were pre-incubated in (A) DMEM containing $0.8 \mathrm{mM}$ L-leucine or (B) DMEM minus leucine for $1 \mathrm{~h}$ followed by the incubation in (A) DMEM minus leucine or (B) DMEM containing $0.8 \mathrm{mM}$ L-Leucine for up to $30 \mathrm{~min}$. (A and B) Proteins were resolved by SDS-PAGE and Western blotted using antisera against the proteins indicated. The results are the mean \pm S.E.M for at least three independent experiments. ${ }^{*} P<0.05, * * P<0.01$ and $* * * P<0.001$ compared with control (i.e., 0 min time point). (C) Left 2 bars: INS1E cells pre-incubated in DMEM $+0.8 \mathrm{mM}$ Leu for $1 \mathrm{~h}$ followed by incubation in DMEM minus Leu for $10 \mathrm{~min}$; right 2 bars: pre-incubated in DMEM minus Leu for $1 \mathrm{~h}$ followed by incubation in DMEM + $0.8 \mathrm{mM}$ Leu for $10 \mathrm{~min}$. The cells were harvested and the intracellular concentration of leucine determined by HPLC.

http://jme.endocrinology-journals.org DOI: 10.1530/JME-15-0212
(C) 2016 Society for Endocrinology Printed in Great Britain
Published by Bioscientifica Ltd 
A

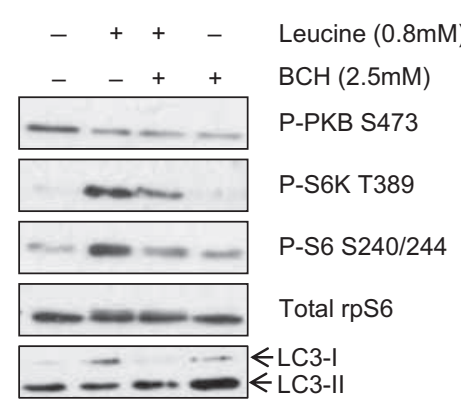

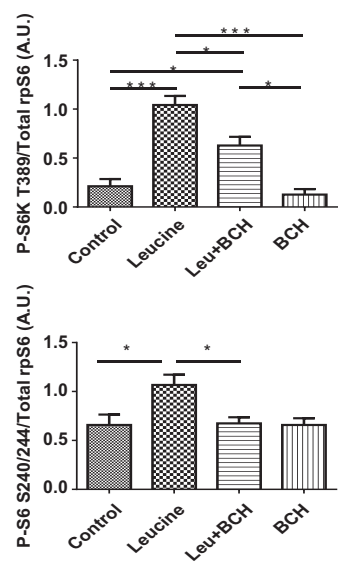

B
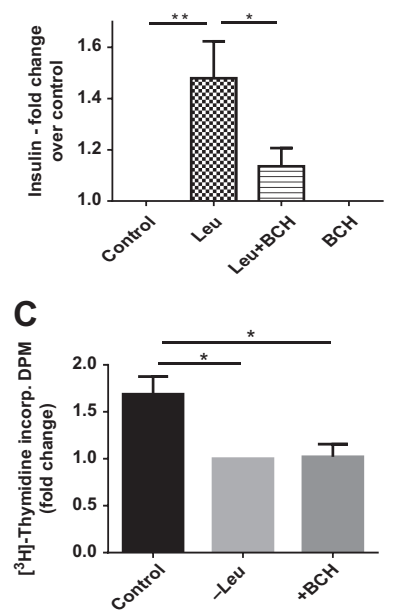

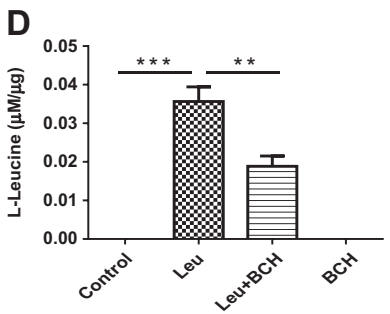

E

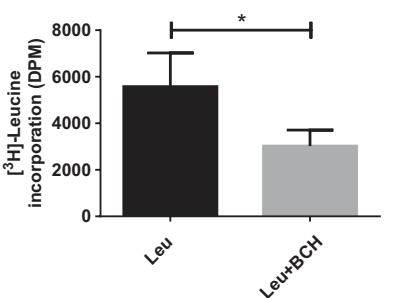

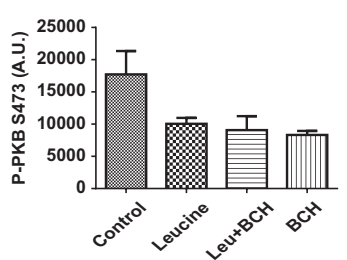

Figure 4

System- $L$ transporters play an important role in regulating islet signalling and function. Rat islets of Langerhans were incubated in DMEM minus L-leucine for $1 \mathrm{~h}$ before a 30-min incubation in DMEM plus or minus $0.8 \mathrm{mM}$ leucine in the presence or absence of $2.5 \mathrm{mM}$ BCH. (A) Proteins were resolved by SDS-PAGE, and Western blotted using antisera against the proteins indicated. Graphical representation of the results is shown below. (B) Insulin secretion assay performed by ELISA on the test medium collected at the end of above treatment. (C) Islets of Langerhans were incubated in RPMI supplemented with $0.2 \%$ FBS for $24 \mathrm{~h}$. The medium was replaced with DMEM minus leucine or DMEM containing 0.8 mM leucine in the presence or absence of $2.5 \mathrm{mM} \mathrm{BCH}$ for $48 \mathrm{~h} .2 \mu \mathrm{Ci}\left[{ }^{3} \mathrm{H}\right]$ thymidine was added for the last $24 \mathrm{~h}$. (D) Rat islets of Langerhans were incubated in DMEM minus L-leucine for $1 \mathrm{~h}$ before a 30-min incubation in DMEM plus or minus $0.8 \mathrm{mM}$ leucine in the presence or absence of $2.5 \mathrm{mM}$ BCH. Cells were harvested for HPLC analysis and the intracellular leucine concentration determined as described in Materials and Methods. (E) L- $\left[4,5-{ }^{3} \mathrm{H}\right]$ Leucine uptake in the presence of $0.8 \mathrm{mM}$ leucine in either the presence $(+\mathrm{BCH})$ or absence $(-\mathrm{BCH})$ of $2.5 \mathrm{mM} \mathrm{BCH}$. All results presented are the mean \pm s.E.M for at least three independent experiments. ${ }^{* *} P<0.001, * * P<0.01, * P<0.05$

Leucine can also stimulate insulin secretion (Newsholme et al. 2007), therefore, in order to ascertain the role of System-L transporters in leucine-stimulated insulin secretion, rat islets of Langerhans were incubated in leucine-depleted media for $1 \mathrm{~h}$ before addition of leucine for $30 \mathrm{~min}$ in the presence or absence of $\mathrm{BCH}$. As anticipated, leucine stimulated insulin secretion, but this was significantly inhibited by the presence of $\mathrm{BCH}$ (Fig. 4B), showing that leucine-dependent stimulation of insulin secretion is dependent upon System-L transport activity.

As mTORC1 activation promotes $\beta$-cell proliferation (Xie et al. 2014), the role of System-L transporters on islet cell proliferation was also investigated. Dispersed islets were incubated either in the absence of l-leucine or in the presence of $\mathrm{BCH}$, and islet cell proliferation was measured by the incorporation of $\left[{ }^{3} \mathrm{H}\right]$ thymidine into DNA (Fig. $4 \mathrm{C}$ ). The addition of $\mathrm{BCH}$ or the removal of leucine significantly inhibited islet cell proliferation. Thus, System-L transporter activity is required for islet cell proliferation.
To investigate the effect of $\mathrm{BCH}$ or leucine withdrawal on the intracellular leucine concentration, HPLC amino acid analysis was performed (Fig. 4D). The removal of leucine caused the depletion in leucine, whereas its re-addition restored intracellular leucine concentration. The re-addition of leucine in the presence of $\mathrm{BCH}$ caused a significant decrease in the intracellular concentration of leucine, indicating that leucine uptake is mediated by System-L transporter (Fig. 4D). Moreover, $\left[{ }^{3} \mathrm{H}\right]$ leucine uptake into cells was significantly inhibited by $\mathrm{BCH}$ (Fig. 4E), providing further evidence that System-L transporters play a significant role in leucine transport into islets.

\section{System- $L$ transporter expression and function in islets of Langerhans}

Having established that System-L transporters play a significant role in $\beta$-cell signalling, we wished to investigate which of the System-L transporters were likely responsible. There are four System-L amino acid: LAT1, LAT2, LAT3

Published by Bioscientifica Ltd 
A

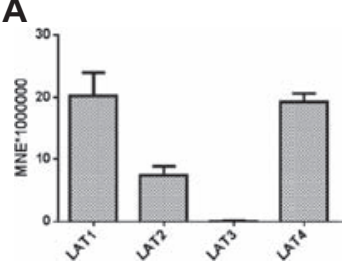

B

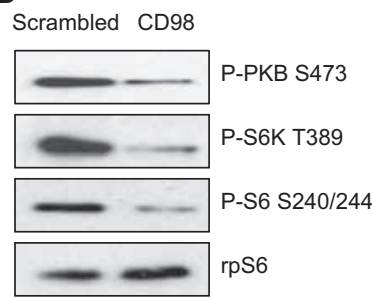

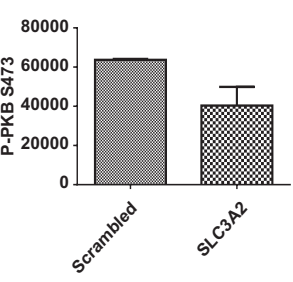

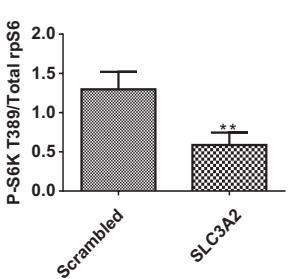

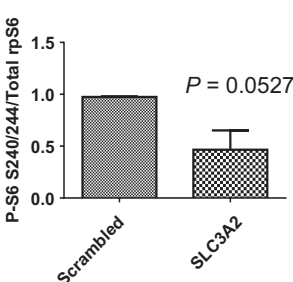

Figure 5

LAT1 is highly expressed in primary islets. (A) qPCR analysis of LAT1, LAT2, LAT3 and LAT4 expression in isolated rat islets of Langerhans expressed as fold change in expression of the target genes (Lat1, Lat2, Lat3 and Lat4) relative to the reference gene (18S RNA). The mean normalized expression (MNE) of the target genes was calculated using $2^{-\Delta \Delta C T}$ method. Expression values were multiplied by $10^{6}$ for clarity of presentation. The results presented are the mean \pm S.E.M of three independent experiments. (B) Rat islets of Langerhans were transfected with siRNAs against: CD98(S/c3a2) or scrambled siRNA as control. After $72 \mathrm{~h}$ the cells were incubated in DMEM minus Leucine for $1 \mathrm{~h}$, followed by the re-addition of $0.8 \mathrm{mM}$ leucine for $30 \mathrm{~min}$. Proteins were resolved by SDS-PAGE, and Western blotted using antisera against the proteins indicated. The results are graphically represented below showing the mean \pm S.E.M for three independent experiments. $* * * P<0.001, * * P<0.01, * P<0.05$ (A.U. $=$ arbitrary unit).

and LAT4 encoded by SLC7A5, SLC7A8, SLC43A1 and SLC43A2, respectively (Kanai et al. 1998, Mastroberardino et al. 1998, Pineda et al. 1999, Segawa et al. 1999). In order to assess their relative expression in primary rat islets, quantitative real-time polymerase chain reaction (qRT-PCR) was performed (Fig. 5A). LAT1, LAT2 and LAT4 were all expressed in islets, although LAT1 and LAT4 were found to be the most abundantly expressed System-L transporters.

Both LAT1 and LAT2 are obligate heterodimers that require $\mathrm{CD} 98$ for function. Therefore, to inhibit the function of both LAT1 and LAT2, and not LAT3 and LAT4, the expression of CD98 was downregulated using siRNA (Fig. 5B). Knockdown of CD98 caused a significant decrease in the activation of mTORC1 as determined by the phosphorylation of S6K. There was also a trend towards a decrease in both PKB and rpS6 phosphorylation, but these changes proved statistically insignificant. Taken together these data would suggest that LAT1 likely plays a significant role in regulating mTORC1 in $\beta$-cells

\section{LAT1 plays an important role in islet signalling to mTORC1 in islets of Langerhans}

As LAT1 is the abundantly expressed System-L transporter in the islets and siRNA-mediated knockdown of CD98 inhibits mTORC1 (Fig. 5), we focused on the role of LAT1 in islets. Two distinct siRNAs directed against the mRNA encoding LAT1 (Slc7a5) (labelled LAT1-A and LAT1-B) were transfected into dispersed islet cells (Fig. 6). The efficiency of LAT1 knockdown, as determined by qRT-PCR quantification, was approximately $41 \%$ and 59\% using siRNAs LAT1-A and LAT1-B, respectively (Fig. 6C and D). The knockdown of LAT1 expression using both siRNAs had no detectable effect on cell morphology (unpublished observations) but caused a significant decrease in L-leucine-stimulated phosphorylation of S6K1 at Thr389, demonstrating that LAT1 is required for mTORC1 activation (Fig. 6A and B). It also consistently caused a decrease in the phosphorylation of rpS6 at Ser240/244; however, this proved statistically insignificant. Interestingly, the knockdown of LAT1 using siRNA LAT1-B significantly inhibited PKB phosphorylation. Although no statistically significant change in the phosphorylation of PKB was detected using siRNA-A, there was a trend towards a decrease in PKB phosphorylation. In conclusion, the System-L transporter LAT1 plays an important role in signalling to $\mathrm{mTORC} 1$ and possibly PKB in islet cells.

\section{LAT1 plays an important role in islet function and proliferation in islets of Langerhans}

To investigate the role of LAT1 in islet function and proliferation, the expression of LAT1 was knockeddown in dispersed islets of Langerhans using siRNA. siRNA-mediated reduction in LAT1 expression significantly inhibited leucine-stimulated insulin secretion (Fig. 7A). Moreover, islet cell proliferation, as determined by the incorporation of $\left[{ }^{3} \mathrm{H}\right]$ thymidine into DNA, was also significantly inhibited (Fig. 7B). In conclusion, the System-L transporter LAT1 plays an important role in islet cell proliferation and insulin secretion. Although a reduction in LAT1 expression decreases mTORC1 activation, and findings from others and our studies have shown that mTORC1 is required for $\beta$-cell proliferation (Balcazar et al. 2009, Xie et al. 2014), it is difficult to confirm whether the effects of reducing LAT1 expression on proliferation is indeed mediated by the inhibition of mTORC1. However, these effects are unlikely due to the potential positive effects of leucine on insulin

Published by Bioscientifica Ltd. 
A
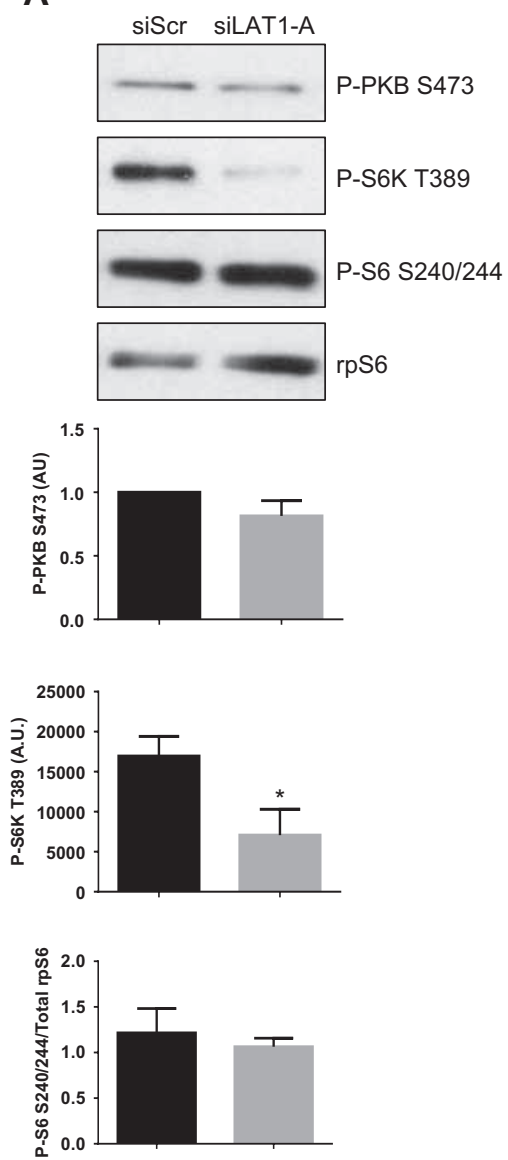

B
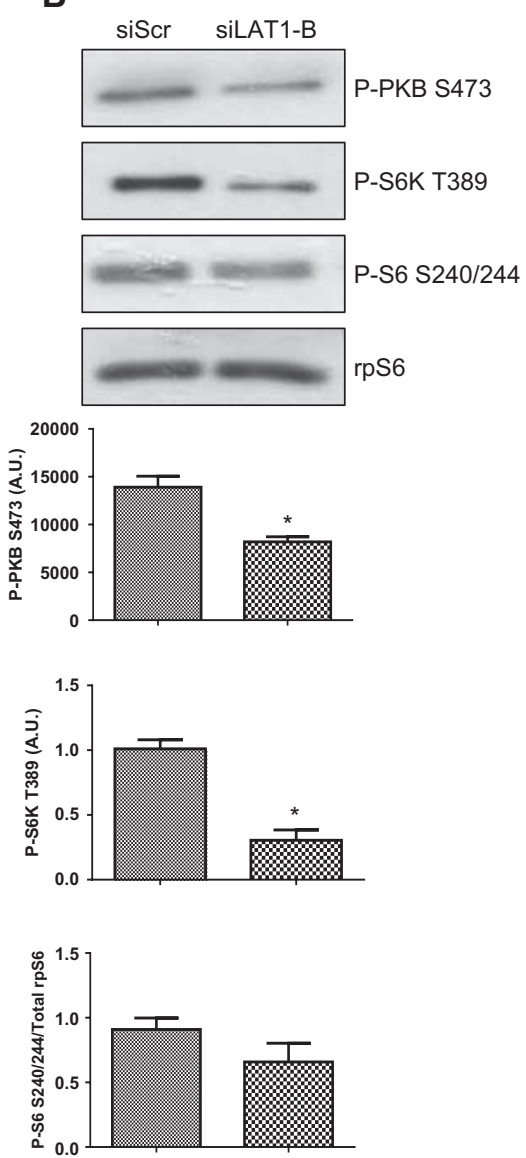

C

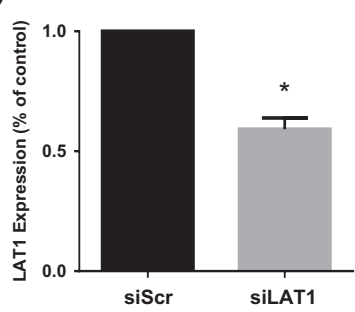

D

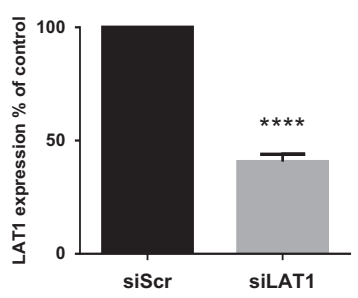

\section{Figure 6}

LAT1 couples to mTORC1 signalling in islet cells. Rat islets of Langerhans were transfected with siRNAs against: (A) LAT1 (S/c7a5) (INVITROGEN s132356) (siLAT1-A) or scrambled siRNA (siScr) as control, (B) LAT1 (S/C7a5) (Dharmacon, SMART POOL on TARGET) (siLAT1-B) or scrambled siRNA (siScr) as control. After $72 \mathrm{~h}$ the cells were incubated in DMEM minus leucine for $1 \mathrm{~h}$, followed by the re-addition of $0.8 \mathrm{mM}$ leucine for 30 min. Proteins were resolved by SDS-PAGE and Western blotted using antisera against the proteins indicated. The results are graphically represented below showing the mean \pm S.E.M for three independent experiments. $* * * P<0.001, * * P<0.01, * P<0.05$ (A.U. $=$ arbitrary unit). (C and D) Quantification of LAT1 expression in dispersed rat islets by qPCR after $72 \mathrm{~h}$ of transfection with (C) LAT1 (SIC7a5) (Dharmacon, SMART POOL on TARGET) or (D) (INVITROGEN s132356). Mean \pm S.E.M for three independent experiments. $* * * P 0.001, * * P<0.01, * P<0.05$ (A.U. = arbitrary unit).

secretion, as these experiments were carried out in nutrientrich media containing a high concentration of glucose.

\section{Discussion}

In this report, we provide evidence that System-L transporters, and in particular LAT1, play a critical role in $\beta$-cell signalling to mTORC1 and the maintenance of $\beta$-cell function and proliferation. LAT1 is highly expressed in rat, mouse and human islets of Langerhans ((Fig. 5) and (Fukushima et al. 2010, Nakada et al. 2014, Zhou et al. 2014)) and is also highly expressed in testicular sertoli cells, ovarian follicular cells and proximal to proliferative zones in the gastrointestinal mucosa (Nakada et al. 2014). In addition, LAT1 is widely expressed in non-epithelial cells showing its highest expression in endothelial cells forming the blood-brain barrier in the brain, indicating that it is also important in transporting amino acids across endothelial-epithelial secretory barriers such as bloodbrain barrier (Mastroberardino et al. 1998, Verrey 2003). As LAT1 expression is upregulated in a range of tumours and is widely expressed in foetal tissue, LAT1 is thought to be particularly important in transporting amino acids into highly proliferating cells (Nakada et al. 2014, Yanagisawa et al. 2014). As LAT1 is an obligate amino acid exchanger, its activity is not only governed by extracellular amino acid concentration but also by the intracellular amino acid concentration controlled by, for example, metabolism and the activity and expression of other amino acid transporters (Meier et al. 2002, Verrey 2003). These include 
A

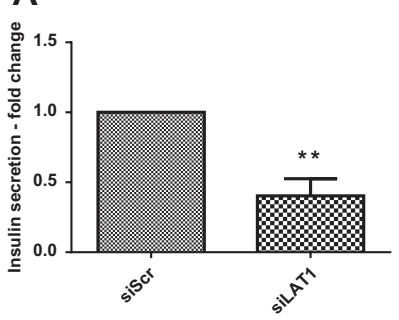

B

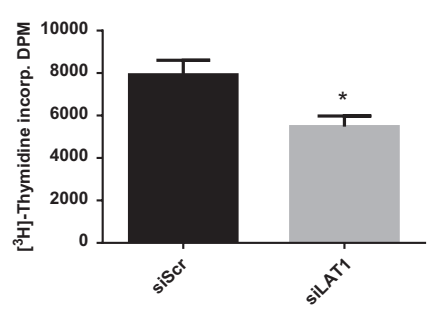

Figure 7

LAT1 is required for islet cell function and proliferation. Dispersed rat islets of Langerhans were transfected with siRNAs against: (A) LAT1 (S/c7a5) or scrambled siRNA as control. After $72 \mathrm{~h}$ the cells were incubated in DMEM minus leucine for $1 \mathrm{~h}$ followed by the re-addition of $0.8 \mathrm{mM}$ leucine for $30 \mathrm{~min}$. An Insulin ELISA assay from on the test media collected after treatments. (B) Dispersed rat islets of Langerhans were transfected with LAT1 (S/c7a5) or scrambled siRNA as control and incubated for $72 \mathrm{~h} .1 \mu \mathrm{Ci} / \mathrm{ml}^{3} \mathrm{H}$-thymidine was added in the last $24 \mathrm{~h}$.

the sodium-dependent System-A transporters, such as SNAT2, which transport small neutral amino acids such as glutamine and alanine, which act as substrates for LAT1 to drive the transport of BCAA and aromatic amino acid into the cell (Evans et al. 2007). The reported Km of LAT1 for BCAAs is approximately $50-100 \mu \mathrm{M}$, whereas for leucine it is between 18 and $62 \mu \mathrm{M}$ (Meier et al. 2002). We show that the EC50 for leucine activation of mTORC1 in INS1E cells was approximately $200 \mu \mathrm{M}$, well within the physiological relevant range of plasma leucine concentration, which is between 100 and $400 \mu \mathrm{M}$. The difference between the EC50 for leucine-stimulated mTORC1 activation and the $\mathrm{Km}$ for LAT1 could be due to the factors independent of transport required for the activation of mTORC1, or they could be simply due to differences in cell systems and experimental conditions. Another possibility is that other amino acid transporters also play an important role in leucine uptake into $\beta$-cells, such as LAT4. LAT4 was also found to be highly expressed in islets (Fig 5) and this transporter has a $\mathrm{Km}$ of approximately $3 \mathrm{mM}$ for leucine (Bodoy et al. 2005).

As the combined fasting concentration of System-L AA substrates is approximately $650 \mu \mathrm{M}$ (Bergstrom et al. Kidney Int. 1990), LAT1 is likely operating near saturation. Thus changes in the expression of LAT1 will increase BCAA uptake. LAT1 expression is upregulated not only by growth factors via the activation of mTORC 1 but also by ER stress, probably via ATF4 (Harding et al. 2003, Liu et al. 2004, Wang et al. 2011a, Krokowski et al. 2013, Cnop et al. 2014). As $\beta$-cells undergo ER stress in the face of obesity and insulin resistance, it is possible that LAT1 expression is increased, which in turn leads to increased mTORC1 activation and a compensatory increase in $\beta$-cell function and mass. Therefore, it is important to establish whether there are changes in LAT1 expression in $\beta$-cells during both the progression of obesity and type 2 diabetes.

Amino acid transporters have also been proposed to act as receptors that sense changes in the extracellular/ intracellular amino acids concentration, possibly by monitoring amino acid flux through the transporter, to transduce an intracellular signal (Hundal \& Taylor 2009). For example, SNAT2 has been proposed to act as a 'transceptor' and regulate PKB activity (Evans et al. 2007, 2008). Interestingly, $\mathrm{BCH}$ inhibited $\mathrm{PKB}$ activation. In addition, knockdown of LAT1 also inhibited PKB activity. How System-L transporters influence PKB activity is unknown, although it may be independent of the intracellular concentration of BCAA. Interestingly, the effects of $\mathrm{BCH}$ on signalling to mTORC1 and PKB are much stronger than that of amino acid withdrawal, despite the fact that amino acid withdrawal results in a greater effect on the intracellular level of leucine/BCAA. The reason for this is not entirely clear, but a possible explanation is that signalling to mTORC1 and PKB is more responsive to the L-leucine/transporter complex than it is to the free cytosolic L-Leu concentration (Hundal \& Taylor 2009).

As BCAA can activate mTORC1, a kinase that stimulates increased pancreatic $\beta$-cell mass and function (for review see (Xie \& Herbert 2012)), increased LAT1 expression or activity may be anti-diabetogenic. However, the chronic hyperactivation of mTORC1 inhibits insulin/ growth factor signalling mediated by ribosomal protein S6 kinase (S6K) inhibitory phosphorylation of insulin receptor substrate (Um et al. 2004, 2006). Indeed, although $\beta$-cell-specific mTORC1 gain-of-function mutant adult mice have initially increased $\beta$-cell function and mass (Shigeyama et al. 2008, Hamada et al. 2009) with age, there is a decline in $\beta$-cell function and mass mediated by feedback inhibition of mTORC1 and the induction of autophagy (Shigeyama et al. 2008, Bartolomé et al. 2014). Interestingly, obese diabetic humans have increased circulating levels of BCAA, which is predictive of T2DM progression (Newgard et al. 2009, Fiehn et al. 2010, Wang et al. 2011b). Thus, it is plausible that elevated BCAA may cause chronic activation of mTORC1 in $\beta$-cells. This could result in a critical switch from mTORC1 stimulating $\beta$-cell growth to causing $\beta$-cell dysfunction, death and the onset of diabetes. Moreover, it has recently been reported that increased amino acid flux, mediated by increased AA transporter expression, exacerbates ER stress-induced $\beta$-cell death and diabetes in the Akita mouse (Krokowski et al. 2013). Hence, although BCAA likely plays an important

Published by Bioscientifica Ltd 
positive role in maintaining glucose homeostasis, chronic increase in circulating BCAA may be a critical determinant in the development of type 2 diabetes. Although this report focuses on the role of LAT1 in $\beta$-cell signalling and function, LAT2 and LAT4 were also found to be expressed in both clonal $\beta$-cells and islets of Langerhans and thus are also likely to play important roles in the $\beta$-cell.

\section{Declaration of interest}

The authors declare that there is no conflict of interest that could be perceived as prejudicing the impartiality of the research reported.

\section{Funding}

This work did not receive any specific grant from any funding agency in the public, commercial, or not-for-profit sector.

\section{Author contributions}

TPH conceived and designed the study. $A B$ helped in the design of the study and provided invaluable intellectual and technical advice. QC, VDB, JB, SC and TPH conducted the experiments. QC, VDB and TPH analysed the results. TPH wrote the manuscript and all authors approved the final version of the manuscript.

\section{Acknowledgements}

The authors thank Dr E Gomez for critical reading of this manuscript.

\section{References}

Balcazar N, Sathyamurthy A, Elghazi L, Gould A, Weiss A, Shiojima I, Walsh K \& Bernal-Mizrachi E 2009 mTORC1 activation regulates beta-cell mass and proliferation by modulation of cyclin D2 synthesis and stability. Journal of Biological Chemistry 284 7832-7842. (doi:10.1074/jbc.M807458200)

Bar-Peled L \& Sabatini DM 2014 Regulation of mTORC1 by amino acids. Trends in Cell Biology 24 400-406. (doi:10.1016/j.tcb.2014.03.003)

Bartolomé A, Kimura-Koyanagi M, Asahara S-I, Guillén C, Inoue H, Teruyama K, Shimizu S, Kanno A, García-Aguilar A, Koike M et al. 2014 Pancreatic $\beta$-cell failure mediated by mTORC1 hyperactivity and autophagic impairment. Diabetes 63 2996-3008. (doi:10.2337/ db13-0970)

Blandino-Rosano M, Chen AY, Scheys JO, Alejandro EU, Gould AP, Taranukha T, Elghazi L, Cras-Meneur C \& Bernal-Mizrachi E 2012 mTORC1 signaling and regulation of pancreatic beta-cell mass. Cell Cycle 11 1892-1902. (doi:10.4161/cc.20036)

Bodoy S, Martín L, Zorzano A, Palacín M, Estévez R \& Bertran J 2005 Identification of LAT4, a novel amino acid transporter with system L activity. Journal of Biological Chemistry 280 12002-12011. (doi:10.1074/jbc.M408638200)

Cnop M, Abdulkarim B, Bottu G, Cunha DA, Igoillo-Esteve M, Masini M, Turatsinze J-V, Griebel T, Villate O, Santin I et al. 2014 RNA sequencing identifies dysregulation of the human pancreatic islet transcriptome by the saturated fatty acid palmitate. Diabetes 63 1978-1993. (doi:10.2337/db13-1383)

Elghazi L, Rachdi L, Weiss AJ, Cras-Meneur C \& Bernal-Mizrachi E 2007 Regulation of beta-cell mass and function by the Akt/protein kinase
B signalling pathway. Diabetes, Obesity and Metabolism 9 Suppl 2 147-157. (doi:10.1111/j.1463-1326.2007.00783.x)

Evans K, Nasim Z, Brown J, Butler H, Kauser S, Varoqui H, Erickson JD, Herbert TP \& Bevington A 2007 Acidosis-sensing glutamine pump SNAT2 determines amino acid levels and mammalian target of rapamycin signalling to protein synthesis in L6 muscle cells. Journal of the American Society of Nephrology 18 1426-1436. (doi:10.1681/ ASN.2006091014)

Evans K, Nasim Z, Brown J, Clapp E, Amin A, Yang B, Herbert TP \& Bevington A 2008 Inhibition of SNAT2 by metabolic acidosis enhances proteolysis in skeletal muscle. Journal of the American Society of Nephrology 19 2119-2129. (doi:10.1681/ASN.2007101108)

Fiehn O, Garvey WT, Newman JW, Lok KH, Hoppel CL \& Adams SH 2010 Plasma metabolomic profiles reflective of glucose homeostasis in non-diabetic and type 2 diabetic obese African-American women PLoS One 5 e15234. (doi:10.1371/journal.pone.0015234)

Fukushima D, Doi H, Fukushima K, Katsura K, Ogawa N, Sekiguchi S, Fujimori K, Sato A, Satomi S \& Ishida K 2010 Glutamate exocrine dynamics augmented by plasma glutamine and the distribution of amino acid transporters of the rat pancreas. Journal of Physiology and Pharmacology 61 265-271.

Hamada S, Hara K, Hamada T, Yasuda H, Moriyama H, Nakayama R, Nagata M \& Yokono K 2009 Upregulation of the mammalian target of rapamycin complex 1 pathway by Ras homolog enriched in brain in pancreatic beta-cells leads to increased beta-cell mass and prevention of hyperglycemia. Diabetes 58 1321-1332. (doi:10.2337/ db08-0519)

Harding HP, Zhang Y, Zeng H, Novoa I, Lu PD, Calfon M, Sadri N, Yun C, Popko B, Paules R et al. 2003 An integrated stress response regulates amino acid metabolism and resistance to oxidative stress. Molecular Cell 11 619-633. (doi:10.1016/S1097-2765(03)00105-9)

Harrington LS, Findlay GM, Gray A, Tolkacheva T, Wigfield S, Rebholz H, Barnett J, Leslie NR, Cheng S, Shepherd PR et al. 2004 The TSC1-2 tumor suppressor controls insulin-PI3K signaling via regulation of IRS proteins. Journal of Cell Biology 166 213-223. (doi:10.1083/jcb.200403069)

Hundal HS \& Taylor PM 2009 Amino acid transceptors: Gate keepers of nutrient exchange and regulators of nutrient signalling. American Journal of Physiology. Endocrinology and Metabolism 296 E603-E613. (doi:10.1152/ajpendo.91002.2008)

Hyde R, Taylor PM \& Hundal HS 2003 Amino acid transporters: Roles in amino acid sensing and signalling in animal cells. Biochemical Journal 373 1-18. (doi:10.1042/BJ20030405)

Jewell JL, Russell RC \& Guan K-L 2013 Amino acid signalling upstream of mTOR. Nature Reviews. Molecular Cell Biology 14 133-139. (doi:10.1038/nrm3522)

Kalogeropoulou D, Lafave L, Schweim K, Gannon MC \& Nuttall FQ 2008 Leucine, when ingested with glucose, synergistically stimulates insulin secretion and lowers blood glucose. Metabolism 57 17471752. (doi:10.1016/j.metabol.2008.09.001)

Kanai Y, Segawa H, Miyamoto K, Uchino H, Takeda E \& Endou H 1998 Expression cloning and characterization of a transporter for large neutral amino acids activated by the heavy chain of 4F2 antigen (CD98). Journal of Biological Chemistry 273 23629-23632.

Klionsky DJ, Abeliovich H, Agostinis P, Agrawal DK, Aliev G, Askew DS, Baba M, Baehrecke EH, Bahr BA, Ballabio A et al. 2008 Guidelines for the use and interpretation of assays for monitoring autophagy in higher eukaryotes. Autophagy 4 151-175.

Krokowski D, Han J, Saikia M, Majumder M, Yuan CL, Guan B-J, Bevilacqua E, Bussolati O, Bröer S, Arvan P et al. 2013 A selfdefeating anabolic program leads to $\beta$-cell apoptosis in endoplasmic reticulum stress-induced diabetes via regulation of amino acid flux. Journal of Biological Chemistry 288 17202-17213. (doi:10.1074/jbc. M113.466920)

Kwon G, Marshall CA, Liu H, Pappan KL, Remedi MS \& McDaniel ML 2006 Glucose-stimulated DNA synthesis through mammalian http://jme.endocrinology-journals.org

DOI: 10.1530/JME-15-0212
() 2016 Society for Endocrinology Printed in Great Britain 
target of rapamycin (mTOR) is regulated by KATP channels: Effects on cell cycle progression in rodent islets. Journal of Biological Chemistry 281 3261-3267. (doi:10.1074/jbc.M508821200)

Leenders M \& van Loon LJ 2011 Leucine as a pharmaconutrient to prevent and treat sarcopenia and type 2 diabetes. Nutrition Reviews 69 675-689. (doi:10.1111/j.1753-4887.2011.00443.x)

Linn T, Geyer R, Prassek S \& Laube H 1996 Effect of dietary protein intake on insulin secretion and glucose metabolism in insulin-dependent diabetes mellitus. Journal of Clinical Endocrinology and Metabolism $\mathbf{8 1}$ 3938-3943.

Liu XM, Reyna SV, Ensenat D, Peyton KJ, Wang H, Schafer AI \& Durante W 2004 Platelet-derived growth factor stimulates LAT1 gene expression in vascular smooth muscle: Role in cell growth. FASEB Journal 18 768-770. (doi:10.1096/fj.03-0886fje)

Van Loon LJ, Kruijshoop M, Menheere PP, Wagenmakers AJ, Saris WH \& Keizer HA 2003 Amino acid ingestion strongly enhances insulin secretion in patients with long-term type 2 diabetes. Diabetes Care 26 625-630.

Mastroberardino L, Spindler B, Pfeiffer R, Skelly PJ, Loffing J, Shoemaker CB \& Verrey F 1998 Amino-acid transport by heterodimers of $4 \mathrm{~F} 2 \mathrm{hc} / \mathrm{CD} 98$ and members of a permease family. Nature 395 288-291.

Meier C, Ristic Z, Klauser S \& Verrey F 2002 Activation of system L heterodimeric amino acid exchangers by intracellular substrates. EMBO Journal 21 580-589.

Merglen A, Theander S, Rubi B, Chaffard G, Wollheim CB \& Maechler P 2004 Glucose sensitivity and metabolism-secretion coupling studied during two-year continuous culture in INS-1E insulinoma cells. Endocrinology 145 667-678. (doi:10.1210/en.2003-1099)

Moore CEJ, Xie J, Gomez E \& Herbert TP 2009 Identification of cAMPdependent kinase as a third in vivo ribosomal protein S6 kinase in pancreatic beta-cells. Journal of Molecular Biology 389 480-494. (doi:10.1016/j.jmb.2009.04.020)

Moore CE, Omikorede O, Gomez E, Willars GB \& Herbert TP 2011 PERK activation at low glucose concentration is mediated by SERCA pump inhibition and confers preemptive cytoprotection to pancreatic betacells. Molecular Endocrinology 25 315-326. (doi:10.1210/me.2010-0309)

Nakada N, Mikami T, Hana K, Ichinoe M, Yanagisawa N, Yoshida T, Endou H \& Okayasu I 2014 Unique and selective expression of L-amino acid transporter 1 in human tissue as well as being an aspect of oncofetal protein. Histology and Histopathology 29 217-227.

Newgard CB, An J, Bain JR, Muehlbauer MJ, Stevens RD, Lien LF, Haqq AM, Shah SH, Arlotto M, Slentz CA et al. 2009 A branchedchain amino acid-related metabolic signature that differentiates obese and lean humans and contributes to insulin resistance. Cell Metabolism 9 311-326. (doi:10.1016/j.cmet.2009.02.002)

Newsholme P, Bender K, Kiely A \& Brennan L 2007 Amino acid metabolism, insulin secretion and diabetes. Biochemical Society Transactions 35 1180-1186. (doi:10.1042/BST0351180)

Pineda M, Fernandez E, Torrents D, Estevez R, Lopez C, Camps M, Lloberas J, Zorzano A \& Palacin M 1999 Identification of a membrane protein, LAT-2, that Co-expresses with $4 \mathrm{~F} 2$ heavy chain, an L-type amino acid transport activity with broad specificity for small and large zwitterionic amino acids. Journal of Biological Chemistry 274 19738-19744.

Rachdi L, Balcazar N, Osorio-Duque F, Elghazi L, Weiss A, Gould A, Chang-Chen KJ, Gambello MJ \& Bernal-Mizrachi E 2008 Disruption of Tsc2 in pancreatic beta cells induces beta cell mass expansion and improved glucose tolerance in a TORC1-dependent manner. PNAS 105 9250-9255. (doi:10.1073/pnas.0803047105)

Segawa H, Fukasawa Y, Miyamoto K, Takeda E, Endou H \& Kanai Y 1999 Identification and functional characterization of a $\mathrm{Na}^{+}$-independent neutral amino acid transporter with broad substrate selectivity. Journal of Biological Chemistry 274 19745-19751.

Shigeyama Y, Kobayashi T, Kido Y, Hashimoto N, Asahara S, Matsuda T, Takeda A, Inoue T, Shibutani Y, Koyanagi M et al. 2008 Biphasic response of pancreatic beta-cell mass to ablation of tuberous sclerosis complex 2 in mice. Molecular and Cellular Biology 28 2971-2979. (doi:10.1128/MCB.01695-07)

Socha P, Grote V, Gruszfeld D, Janas R, Demmelmair H, ClosaMonasterolo R, Subias JE, Scaglioni S, Verduci E, Dain E et al. 2011 Milk protein intake, the metabolic-endocrine response, and growth in infancy: Data from a randomized clinical trial. American Journal of Clinical Nutrition 94 1776S-1784S. (doi:10.3945/ajcn.110.000596)

Tremblay F, Brûlé S, Hee Um S, Li Y, Masuda K, Roden M, Sun XJ, Krebs M, Polakiewicz RD, Thomas G et al. 2007 Identification of IRS-1 Ser-1101 as a target of S6K1 in nutrient- and obesity-induced insulin resistance. PNAS 104 14056-14061. (doi:10.1073/pnas.0706517104)

Um SH, Frigerio F, Watanabe M, Picard F, Joaquin M, Sticker M, Fumagalli S, Allegrini PR, Kozma SC, Auwerx J et al. 2004 Absence of S6K1 protects against age- and diet-induced obesity while enhancing insulin sensitivity. Nature 431 200-205. (doi:10.1038/nature02866)

Um SH, D'Alessio D \& Thomas G 2006 Nutrient overload, insulin resistance, and ribosomal protein S6 kinase 1, S6K1. Cell Metabolism 3 393-402. (doi:10.1016/j.cmet.2006.05.003)

Verrey F 2003 System L: Heteromeric exchangers of large, neutral amino acids involved in directional transport. Pflugers Archiv 445 529-533. (doi:10.1007/s00424-002-0973-z)

Wang Q, Bailey CG, Ng C, Tiffen J, Thoeng A, Minhas V, Lehman ML, Hendy SC, Buchanan G, Nelson CC et al. 2011a Androgen receptor and nutrient signaling pathways coordinate the demand for increased amino acid transport during prostate cancer progression. Cancer Research 71 7525-7536. (doi:10.1158/0008-5472.CAN-11-1821)

Wang TJ, Larson MG, Vasan RS, Cheng S, Rhee EP, McCabe E, Lewis GD, Fox CS, Jacques PF, Fernandez C et al. 2011b Metabolite profiles and the risk of developing diabetes. Nature Medicine 17 448-453. (doi:10.1038/nm.2307)

Xie J \& Herbert TP 2012 The role of mammalian target of rapamycin (mTOR) in the regulation of pancreatic beta-cell mass: Implications in the development of type 2 diabetes. Cellular and Molecular Life Sciences 69 1289-1304. (doi:10.1007/s00018-011-0874-4)

Xie J, El Sayed NM, Qi C, Zhao X, Moore CE \& Herbert TP 2014 Exendin-4 stimulates islet cell replication via the IGF1 receptor activation of mTORC1/S6K1. Journal of Molecular Endocrinology $\mathbf{5 3}$ 105-115. (doi:10.1530/JME-13-0200)

Xu G, Kwon G, Marshall CA, Lin TA, Lawrence Jr. JC \& McDaniel ML 1998 Branched-chain amino acids are essential in the regulation of PHAS-I and p70 S6 kinase by pancreatic beta-cells. A possible role in protein translation and mitogenic signaling. Journal of Biological Chemistry 273 28178-28184.

Yanagisawa N, Hana K, Nakada N, Ichinoe M, Koizumi W, Endou H, Okayasu I \& Murakumo Y 2014 High expression of L-type amino acid transporter 1 as a prognostic marker in bile duct adenocarcinomas. Cancer Medicine 3 1246-1255. (doi:10.1002/cam4.272)

Yang J, Wong RK, Park M, Wu J, Cook JR, York DA, Deng S, Markmann J, Naji A, Wolf BA et al. 2006 Leucine regulation of glucokinase and ATP synthase sensitizes glucose-induced insulin secretion in pancreatic beta-cells. Diabetes 55 193-201.

Zhou Y, Waanders LF, Holmseth S, Guo C, Berger UV, Li Y, Lehre A-C, Lehre KP \& Danbolt NC 2014 Proteome analysis and conditional deletion of the EAAT2 glutamate transporter provide evidence against a role of EAAT2 in pancreatic insulin secretion in mice. Journal of Biological Chemistry 289 1329-1344. (doi:10.1074/jbc. M113.529065)

Received in final form 30 November 2015

Accepted 8 December 2015

Accepted Preprint published online 8 December 2015 http://jme.endocrinology-journals.org

DOI: 10.1530/JME-15-0212
() 2016 Society for Endocrinology Printed in Great Britain
Published by Bioscientifica Ltd 